\title{
Micropaleontology and Biostratigraphy of Zgaimat Al-Hasah Anticline, SE-Jordan
}

\author{
Habes Mohammad Al-Mashakbeh \\ Department of Applied Earth and Environmental Sciences, Al al-Bayt University, Mafraq, Jordan \\ Email: Habes2819@aabu.edu.jo
}

How to cite this paper: Al-Mashakbeh, H.M. (2020) Micropaleontology and Biostratigraphy of Zgaimat Al-Hasah Anticline, SE-Jordan. Open Journal of Geology, 10, 1234-1249.

https://doi.org/10.4236/ojg.2020.1012061

Received: August 18, 2020

Accepted: November 26, 2020

Published: December 29, 2020

Copyright (c) 2020 by author(s) and Scientific Research Publishing Inc. This work is licensed under the Creative Commons Attribution International License (CC BY 4.0).

http://creativecommons.org/licenses/by/4.0/

\begin{abstract}
This study presents the first attempt to recognize the planktonic foraminiferal biozones and to determine the time of deposition of the carbonate deposits exposed in the Zgaimat Al-Hasah anticline, Southeastern Jordan. Five equivalent planktonic foraminiferal biozones; Zones E3 (P6a), E4 (P6b), E5 (P7), E6 (P8), and E7 or E7a were identified by analyzing twenty-eight samples from a $20 \mathrm{~m}$ thick section. Ten planktonic foraminiferal species belonging to seven genera and thirteen benthic foraminiferal species representing eleven genera were recorded. An Early Eocene age was assigned to the carbonate deposits exposed in Zgaimat $\mathrm{Al}$-Hasah anticline based on some typical index species of calcareous planktonic foraminifera.
\end{abstract}

\section{Keywords}

Micropaleontology, Biostratigraphy, Planktonic Foraminifera, Early Eocene, Zgaimat Al-Hasah Anticline, Jordan

\section{Introduction}

This study focuses on the planktonic foraminiferal biostratigraphy of the outcrop of Zgaimat Al-Hasah along the fault zone of Zgaimat Al-Hasah in the Wadi Sirhan Basin in the southeastern desert of Jordan, near the border of Saudi Arabia (Figure 1).

The carbonate facies at Zgaimat al-Hasah outcrop studied in general works dealing with the sedimentology and geology of Jordan [1] [2] [3] [4].

Planktonic foraminifera, which is one of the most important fossil groups for local and regional biostratigraphic zonation and correlation [5] [6], has not yet received attention from previous studies conducted in the study area.

Planktonic foraminifera have been deposited over an extensive portion of the world's oceans and seas during various geological periods, and are frequently 


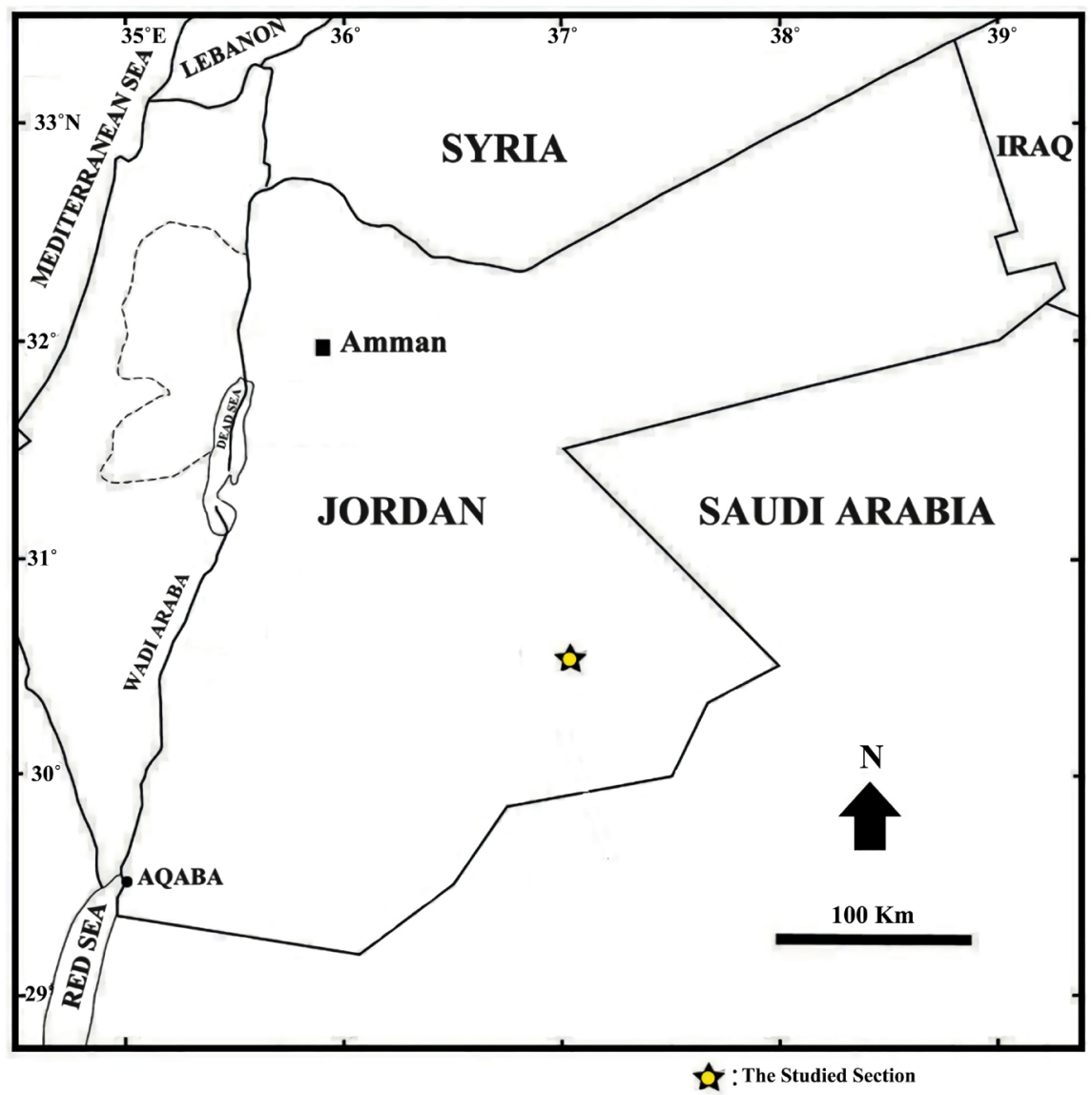

Figure 1. Map of Jordan with the location of the study area.

present in large numbers. The application of planktonic foraminiferal biostratigraphic studies started in the Gulf Coast region of the USA in the middle of the last century and spread rapidly across the world's major oil-producing regions [7] [8].

Many biostratigraphic and zonal planktonic foraminiferal studies have been published from different parts of the world; [6] [9]-[15] and others.

In the present work, a planktonic foraminiferal fauna from 20 meters thick at the exposed outcrop of Zgaimat Al-Hasah in the area has been examined.

Despite the poor preservation and lowly diverse of the species, a biostratigraphical zonation of the deposits was made.

The main objective of this study is concerned with the biostratigraphic zones and age determination of the Zgaimat Al-Hasah outcrop in the Wadi Sirhan Ba$\sin$, moreover, to investigate the vertical distribution of the foraminiferal content in this outcrop at the southeastern desert of Jordan.

\section{Geological Setting}

The foraminiferal fauna studied from the Zgaimat Al-Hasah outcrop, which situated in the Wadi Sirhan Basin.

The Zgaimat Al-Hasah outcrop has situated inside an anticline where the 
Lower and Upper Cretaceous strata form the center [16] [17].

The Zgaimat Al-Hasah anticline is caused by local folding that occurs in several places along the Zgaimat Al-Hasah fault zone and, the folding pattern is representative of (right-side) transcurring movements [18]. The Zgaimat Al-Hasah fault zone is the E-W trend, extending westward from Saudi Arabia for more than 250 kilometers to the Jordan Valley. During the Late Cretaceous period, many basins and swells dominated the seafloor due to compression associated with the northward movement of Arabia as part of the African Plate [19]. Seafloor paleorelief contribute to governing sedimentation patterns and variations of rock thickness and facies. Zgaimat al-Hasah is located in one of these paleohighs known as Bayer-Kilwa's paleo-high [4].

Jordan lay on the southern margin of the Neo-Tethys Ocean during the Cretaceous to Eocene period. Throughout this period of global sea-level rise, regularly transgressed, south and east, over the borders of the Arabian Craton [20]. The sedimentation pattern of the southern passive continental margin of Tethys (including Jordan) is governed principally by three factors. The long-term variations in the climatic eustatic sea level [21] [22]; the structure of the Neo-Tethys Ocean and its spreading center near Cyprus; and the isostatic and intra-plate tectonic deformation of the Arabian Neoproterozoic Shield and its paleozoic sedimentary rocks, to the south and east, which affected terrigenous sediment flux [20]. The Cretaceous successions of Jordan conveniently have been divided into three lithostratigraphic groups (Figure 2); these are described in the upward

\begin{tabular}{|c|c|c|c|c|}
\hline \multicolumn{3}{|c|}{ Chronostratigraphical Units } & \multicolumn{2}{|c|}{ Lithostratigraphical Units } \\
\hline Period & Epoch & Age & Group & Formation \\
\hline \multirow{3}{*}{ : } & & \multirow{2}{*}{ Eocene } & \multirow{8}{*}{$\frac{\tilde{\sigma}}{\frac{\sigma}{d}}$} & Shallaleh \\
\hline & & & & Umm Rijam Chert Limestone \\
\hline & & Paleocene & & \multirow{2}{*}{ Muwaqqar Chalk Marl } \\
\hline \multirow{9}{*}{ 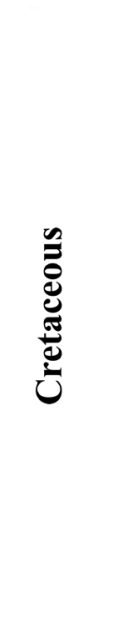 } & \multirow{8}{*}{ 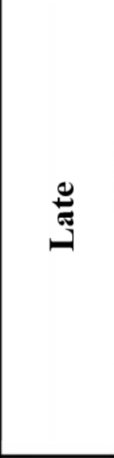 } & \multirow{2}{*}{ Maastrichtian } & & \\
\hline & & & & Al-Hisa Phosphorite \\
\hline & & Campanian & & Amman Silicified Limestone \\
\hline & & Santonian & & \\
\hline & & Coniacian & & Ghudran \\
\hline & & Turonian & \multirow{3}{*}{$\stackrel{\Xi}{\Xi}$} & Wadi Es Sir \\
\hline & & 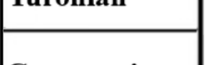 & & \begin{tabular}{|l|} 
Shueib \\
Hummar
\end{tabular} \\
\hline & & Cenomanian & & $\begin{array}{l}\text { Fuheis } \\
\text { Na'ur } \\
\end{array}$ \\
\hline & 렬 & Aptian-Albian & 恶 & \\
\hline
\end{tabular}

Figure 2. Stratigraphy of the Cretaceous-Tertiary units in Jordan. Modified after [20]. 
sequence below. The Kurnub Sandstone Group (Berriasian to Albian) consists mainly of alluvial quartz-arenite in southern and central Jordan, with subdued thin beds of alluvial mudstone and marine limestone and siltstone in northern Jordan [3] [23].

The Ajlun Group (Late Albian/Cenomanian to Mid-Coniacian) composes mainly of shallow marine carbonates [24]. The lithofacies of the group is fluvial siliciclastics in the south and east of Jordan and changed abruptly into basinal facies towards the northwest of Jordan [25]. A major transgression of the Neo-Tethys Ocean is represented by the Ajlun Group and a rimmed inner shelf depositional environment is assigned [20]. The outcrop group is divided into six formations: Naur Limestone, Fuheis, Hummar Limestone, Shueib, Wadi As Sir Limestone, and Jibal Khureij. The Late Cretaceous-Eocene Belqa Group composes mainly of chalk, chert, and phosphorite [24] [26]. The outcrop group is divided into five formations [27]: Wadi Umm Ghudran, Amman, Muwaqqar, Umm Rijam, and Wadi Shallala formations.

One section with coordinates $\left(30^{\circ} 28^{\prime} 28.40^{\prime \prime} \mathrm{N}, 37^{\circ} 6^{\prime} 41.01^{\prime \prime} \mathrm{E}\right)$ was investigated for this study. It is the Zgaimat Al-Hasah anticline, some $52 \mathrm{~km}$ south-southeast of the old Bayer police station. (Figure 3 ) shows the lithology of the studied section. The studied section is underlain by friable to consolidated varicolored sandstones of the Kurnub Group of Early Cretaceous age [2] [3]. The Zgaimat

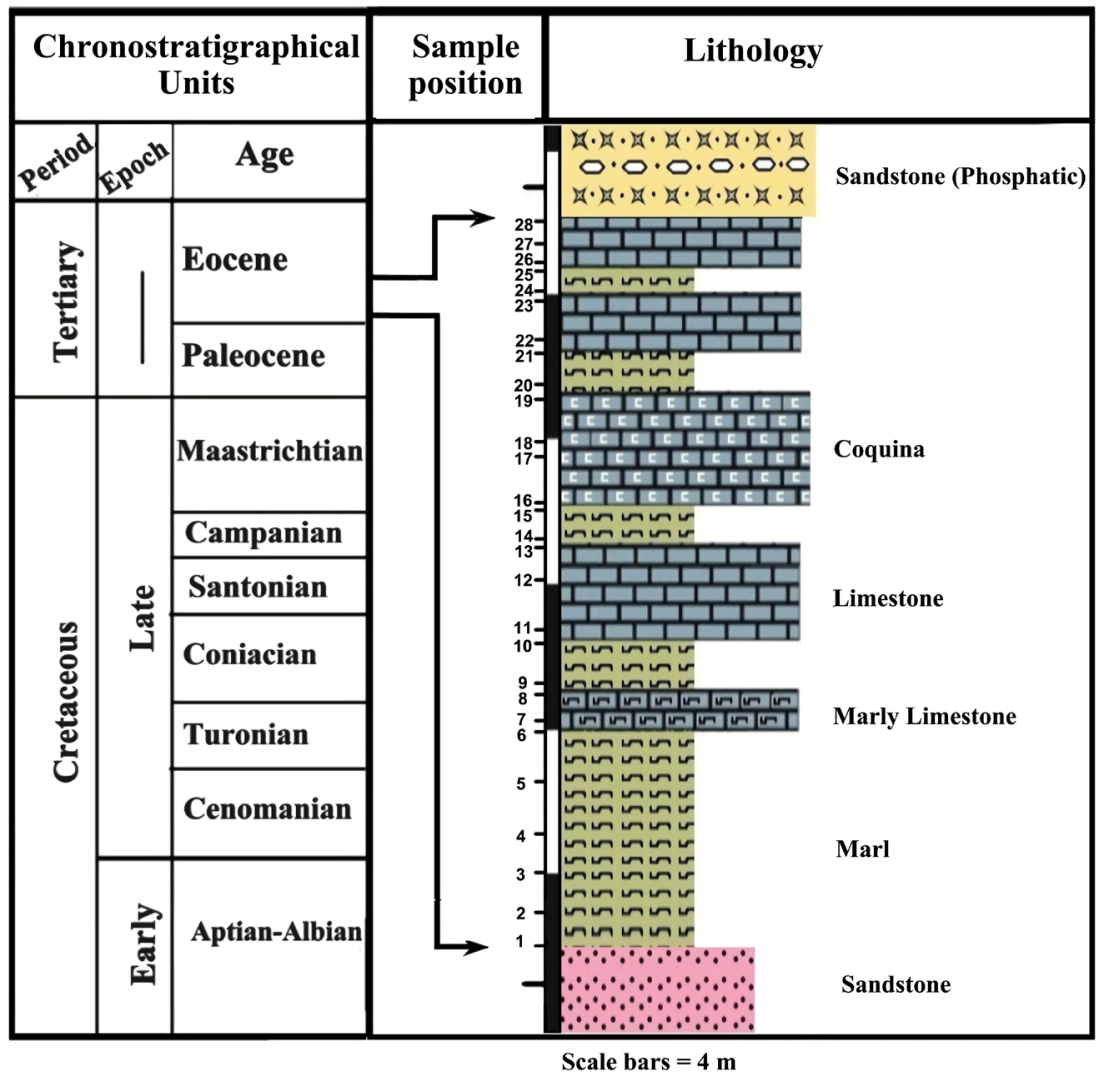

Figure 3. Lithostratigraphic section showing the succession of carbonate deposits in Zgaimat Al-Hasah, southeastern Jordan. 
Al-Hasah section, is represented by the undifferentiated Ajlun Group which in turn is overlain by the Al-Hisa Phosphorite Formation (AHP) from the Belqa Group of the Paleocene-Early Eocene age [28]. The measured section is overlain by a bedded chert horizon (around $2 \mathrm{~m}$ ).

\section{Materials and Methods}

The studied section (Zgaimat Al-Hasah) was sampled for calcareous microfossil analysis. The detailed biostratigraphic study was based on 28 samples from the 20-m-thick studied section. Two additional samples for micropalaeontological analyses were collected from the varicolored sandstones and phosphatic sandstone which are underlain and overlain the studied section respectively (Figure 3 ). Samples were immersed in water with $3 \%$ of hydrogen peroxide and then washed through a $63 \mu \mathrm{m}$ sieve under running water. The fractions dried in an oven, foraminifera were picked out from the fractons and deposited onto micropalaeontological slides.

Biostratigraphic interpretation was compared with the standard planktonic foraminiferal biozonation; [6] new planktonic foraminiferal biozonation (E and O zones) [14] [15] [29] (Figure 4).

The identification of the genera and species of planktonic and benthic foraminiferal is based on; [5] [12] [30]-[35] and [36] is the classification system used here.

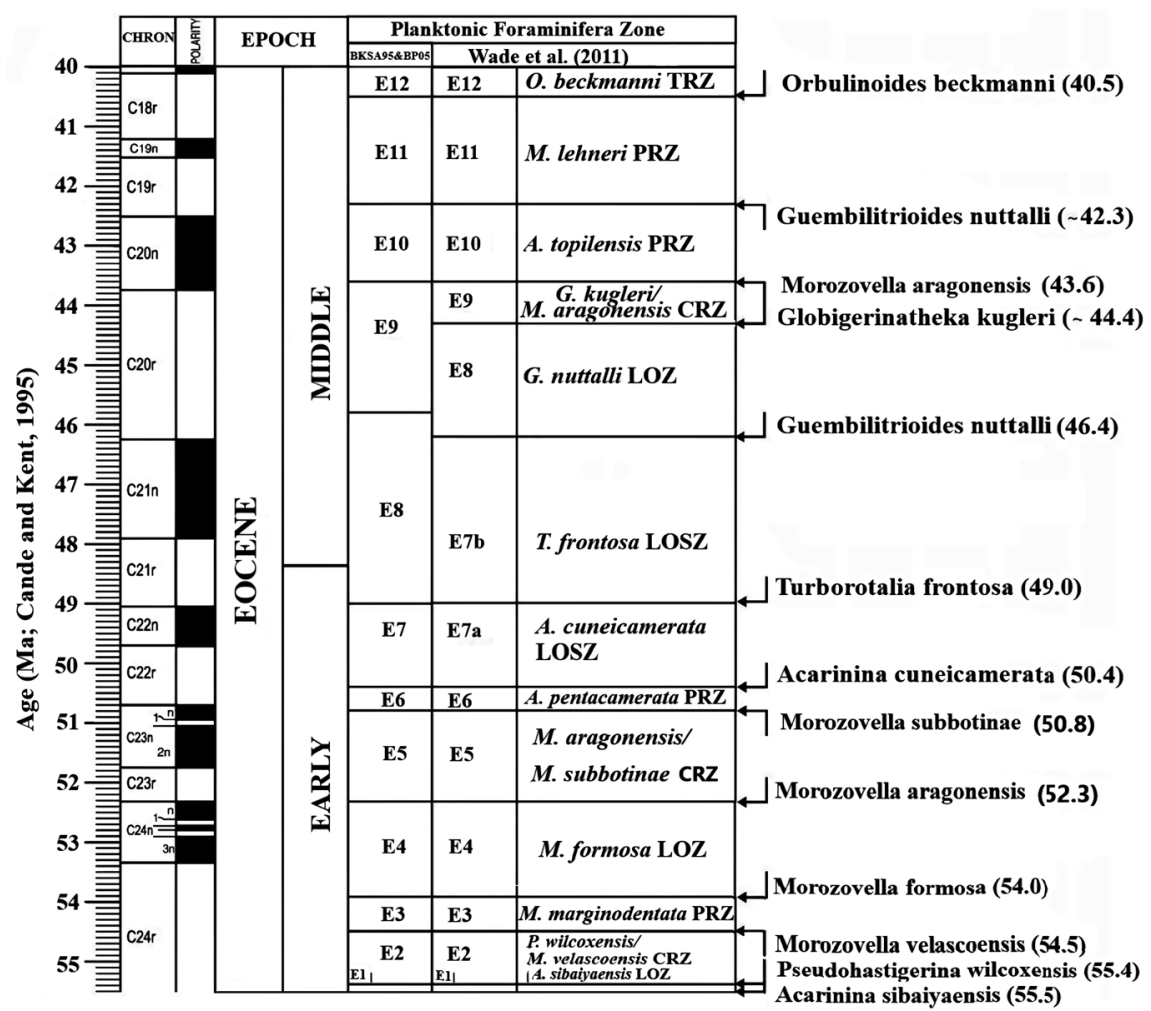

Figure 4. Primary planktonic foraminiferal bioevents for the Cenozoic against the polarity time scale of [41]. BKSA95 $=[6]$; BP05 $=[14]$. 
The planktonic foraminiferal biozone determination was based on the Lowest occurrence (LO) and Highest occurrence (HO) of the taxa in order to avoid possible errors as a result of the mixing of various foraminiferal assemblages in the samples.

Because of the difficulty in identification of most of the zonal marker, the boundary is identified based on the other recognizable taxa.

Microfossil assemblages were examined on research stereo microscope SMZ25, whereas a detailed study of the planktonic foraminiferal morphology was carried out using scanning electron microscope (SEM).

Specimens used for this work are stored at the Department of Applied Earth and Environmental Sciences, $\mathrm{Al}$ al-Bayt University, Jordan.

\section{Lithology}

\subsection{Geology}

\subsubsection{Boundaries}

The base of studied section is marked by clear contact separated the underlying varicoloured Sandstone lithostratigraphic unit from the alternating marl, marly limestone and limestone units. At the top of this section there is noticeable change to gray, hard, medium to thick-bedded of phosphatic sandstone.

\subsubsection{Distribution, Morphology}

The studied section is attributed to the Ajlun Group, it consists of two parts; the lower one is undifferentiated Na'ur, Fuheis, Hummar and Shueib Formations and the upper part is considered to be equivalent to Wadi Es Sir Formation [4].

\subsubsection{Thickness}

The thickness of alternating marl, limestone and marly limestone is about $20 \mathrm{~m}$, and the thickness of the upper unit (phosphatic sandstone) covering the studied section is about $5.5 \mathrm{~m} \mathrm{[4]}$.

\subsubsection{Lithology and Bedform}

The Lithology of this formation consists mainly of yellowish marly limestone with interbedded limestone, and unstratified light yellowish marls, fine to medium-grained with dispersed grey dolomitic limestone and associated with thinly chert beds.

\subsection{Fauna and Age}

The studied section is considered by [4] as an undifferentiated Na'ur, Fuheis, Hummar, and Shueib Formation, belonging to Ajlun Group with significantly reduced thickness. The age of the Ajlun group is Cenomanian-Turonian [37] [38] [39]. The thickness of the Ajlun Group formations increases from approximately $100 \mathrm{~m}$ in the south to more than $600 \mathrm{~m}$ in the north of the country [40]. The section is rich in poor-preserved Echinoiderms and Molluscan fragmented shells such as; Bivalves, Gastropods, Pelecypods, and Cephalopods. Microfossils assemblages include low-preserved planktonic, benthic Foraminifera, and Os- 
tracods species.

\section{Results and Discussion}

\section{Foraminiferal Biostratigraphy}

In the present study, a biostratigraphic sequence and planktonic foraminiferal biozones are defined mainly on the Lowest and Highest Occurrence of some age-diagnostic species due to the absence of biostratigraphic markers of the standard zonations (Figure 5). To some extent, the low preservation of planktonic foraminifera in the samples constrains the application of standard planktonic foraminiferal zonations [6] [14] [15] [29]. However, because of their poor preservation, a number of marker species are sporadically present or missing. The method of zonation is solely based on age-diagnostic species and is basically biostratigraphic in nature.

It is not formally established here but presented to illustrate an ability to define approximate positions within a standard time-stratigraphic scale. Foraminiferal biozone schemes based on an accurate age indicators provide a solid basis for biostratigraphic correlations worldwide and regionally. Zones E3 (P6a), E4 (P6b), E5 (P7), E6 (P8), and E7 or E7a have been identified in the Lower Eocene sedimentary succession (Figure 5).

The biostratigraphic zones are described from the top to the bottom as follows:

Subzone E7a. Acarinina cuneicamerata Lowest-occurrence Subzone

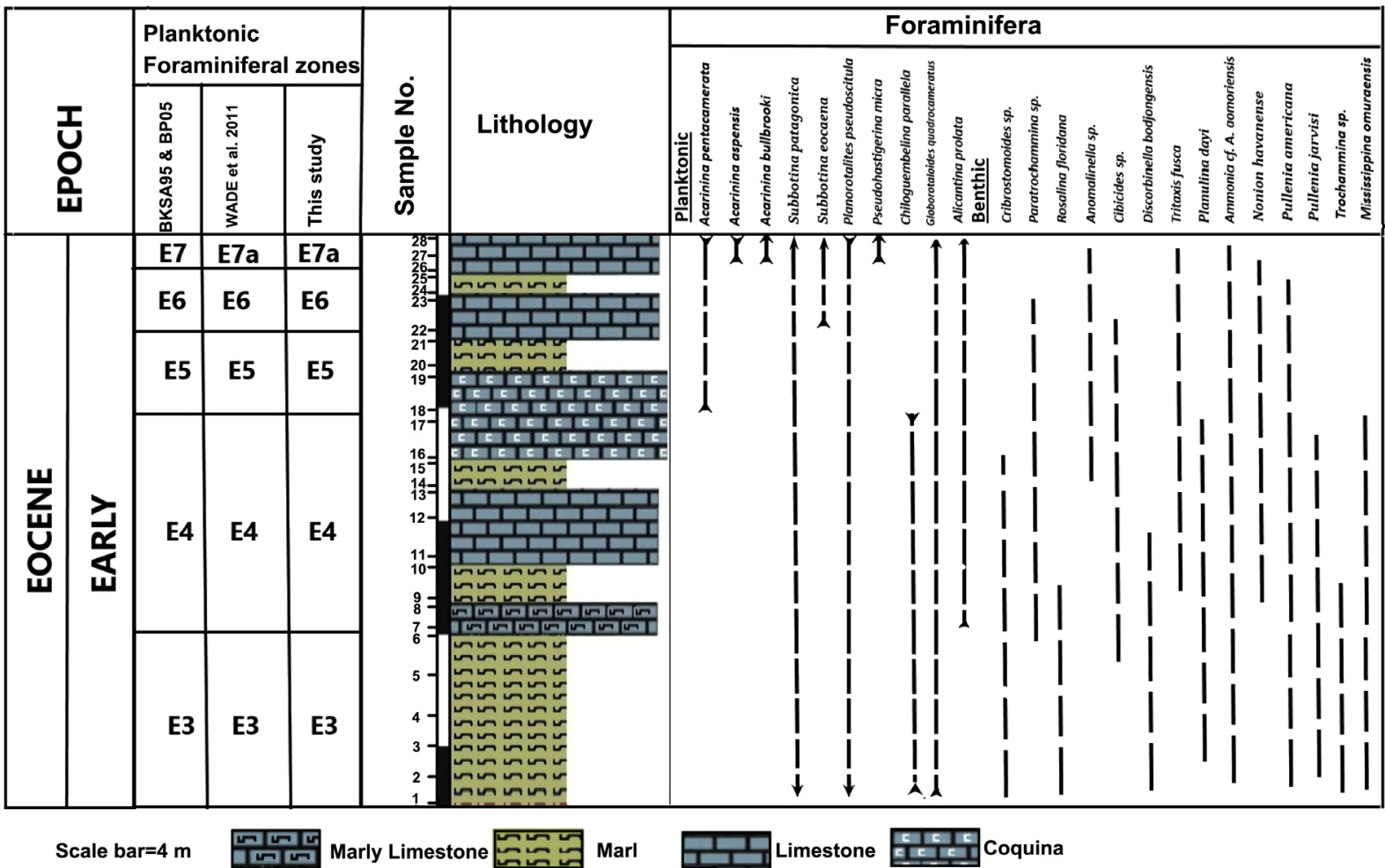

Figure 5. Distribution of planktonic and benthic foraminiferal species in the studied section. 
The Acarinina cuneicamerata Lowest-occurrence Subzone or Subzone E7a was originally established and described by [29] and it is equivalent to Zone E7 of [14]. It is marked by the interval from the LO of the Acarinina cuneicamerata and the LO Turborotalia frontosa. The estimated age is $50.4-49.0 \mathrm{Ma}$ as reported in [41]; $50.3-48.6 \mathrm{Ma}$ as reported in [42] respectively.

The equivalent of Zone E7a or E7 in the studied section can be described as Pseudohastigerina micra Lowest-occurrence Subzone. It is defined by the LO of Pseudohastigerina micra to the $\mathrm{HO}$ of Acarinina pentacamerata within the samples nrs. 27 - 28 collected from the upper part of limestone unit. Pseudohastigerina micra ranges from the mid part of E7a subzone to $\mathrm{O} 1$ zone [43]. The geological range of Acarinina pentacamerata extends from E5 zone (mid lower Eocene) to the upper part of E7a subzone (lower part of middle Eocene) [44]. This zone is covered with occurrence of the nominate species for $1 \mathrm{~m}$ interval in the upper part of the studied section (Figure 5). This interval zone indicates Early Eocene and characterized by low diversified planktonic foraminiferal species, e.g. Globorotaloides quadrocameratus, Alicantina prolata, Subbotina patagonica, Acarinina pentacamerata, Subbotina eocaena, Planorotalites pseudoscitula. Acarinina bullbrooki, Pseudohastigerina micra.

Zone E6. Acarinina pentacamerata Partial-range Zone

The Acarinina pentacamerata Partial-range Zone or Zone E6 was originally established and described by Berggren [14]. It is marked by the interval from the Highest Occurrence (HO) of the Morozovella subbotinae to the Lowest Occurrence (LO) of Acarinina cuneicamerata. The estimated age is $50.8-50.4 \mathrm{Ma}$ as reported in [41]; 50.8 - 50.3 Ma as reported in [42] respectively.

The equivalent of Zone E6 in the studied section can be described as Subbotina eocaena Lowest-occurrence Zone. It is defined by the Lowest Occurrence (LO) of Subbotina eocaena within the sample nrs. 22 - 26 collected from the marl unit. Subbotina eocaena ranges from the early Eocene Zone E6 [45] to upper Oligocene Zone O6 [46]. Pseudohastigerina micra ranges from the mid part of E7a subzone to $\mathrm{O} 1$ zone [43]. This zone is covered with occurrence of the nominate species for $2 \mathrm{~m}$ interval in the upper part of the studied section (Figure 5). This interval zone indicates Early Eocene and characterized by low diversified planktonic foraminiferal species, e.g. Globorotaloides quadrocameratus, Alicantina prolata, Subbotina patagonica, Acarinina pentacamerata, Subbotina eocaena, Planorotalites pseudoscitula.

Zone E5. Morozovella aragonensis/ Morozovella subbotinae Concurrent-range Zone

The Morozovella aragonensis/Morozovella subbotinae Concurrent-range Zone or Zone E5 was described by Berggren [14]. It is marked by the interval between the LO of the Morozovella aragonensis and the $\mathrm{HO}$ of Morozovella subbotinae. The estimated age is $52.3-50.8 \mathrm{Ma}$ as reported by [41] [42].

The equivalent of Zone E5 in the studied section can be described as Acarinina pentacamerata Lowest-occurrence Zone. It is defined by the interval from the Lowest Occurrence (LO) of Acarinina pentacamerata to the LO of Subbotina 
eocaena. The geological range of Acarinina pentacamerata extends from E5 zone (mid lower Eocene) to the upper part of E7a subzone (lower part of middle Eocene) [44]. This zone is represented by $2 \mathrm{~m}$ interval within the samples nrs. 18 21 collected from the limestone/Marl unit of the studied section (Figure 5). This interval zone indicates Early Eocene and characterized by low diversified planktonic foraminiferal species, e.g. Globorotaloides quadrocameratus, Alicantina prolata, Subbotina patagonica, Acarinina pentacamerata, Planorotalites pseudoscitula.

Zone E4. Morozovella formosa Lowest-occurrence Zone.

The Morozovella formosa Lowest-occurrence Zone or Zone E4 was described by Berggren [14]. It is marked by the interval between the LO of the Morozovella formosa and the LO of Morozovella aragonensis. The estimated age is 54.0 - 52.3 $\mathrm{Ma}$ as reported by [41] and 54.4 $-52.3 \mathrm{Ma}$ as estimated by [42]

The equivalent of Zone E4 in the studied section can be described as Alicantina prolata Lowest-occurrence Zone. It is defined by the interval from the Lowest Occurrence (LO) of Alicantina prolata to the LO of Acarinina pentacamerata. The geological range of Alicantina prolata extends from Zone E4 (mid lower Eocene) to E8 (lower part of middle Eocene) [47]. This zone is represented by $11 \mathrm{~m}$ interval within the samples nrs. 7 - 17 collected from the limestone/Marl units of the studied section (Figure 5). This Early Eocene interval zone is characterized by low diversification of planktonic foraminiferal species, e.g. Globorotaloides quadrocameratus, Alicantina prolata, Subbotina patagonica, Subbotina eocaena, Planorotalites pseudoscitula, Chiloguembelina parallela.

Zone E3. Morozovella marginodentata Partial-range Zone

The Morozovella marginodentata Partial-range Zone or Zone E3 was described by Berggren [14]. It is marked by the interval between the HO of the Morozovella velascoensis and the $\mathrm{LO}$ of Morozovella formosa. The estimated age is $54.5-54.0 \mathrm{Ma}$ as reported by [41] and $54.9-54.4 \mathrm{Ma}$ as estimated by [42].

The equivalent of Zone E3 in the studied section can be described as Globorotaloides quadrocameratus Lowest-occurrence Zone. It is defined by the interval from the Lowest Occurrence (LO) of Globorotaloides quadrocameratus to the LO of Alicantina prolata. The geological range of Globorotaloides quadrocameratus extends from Lower Eocene Zone E2 [48] to lower Miocene Zone M1 [49]. This zone is represented by $4 \mathrm{~m}$ interval within the samples nrs. 1 - 6 collected from the Marl unit of the studied section (Figure 5). This Early Eocene interval zone is characterized by poor diversification of planktonic foraminiferal species., e.g. Globorotaloides quadrocameratus, Alicantina prolata, Planorotalites pseudoscitula, Chiloguembelina parallela.

Photographs of selected planktonic and benthic foraminiferal species from the studied section in the Zgaimat Al Hasah anticline were shown in (Figures 6-8). To clarify the details of the external morphology, some specimens were wetted with water and then photographed with the SMZ25 microscope as shown in (Figure 7(1b), Figure 7(1d), Figure 7(4b), Figure 7(4d), and Figure 7(5b)). 


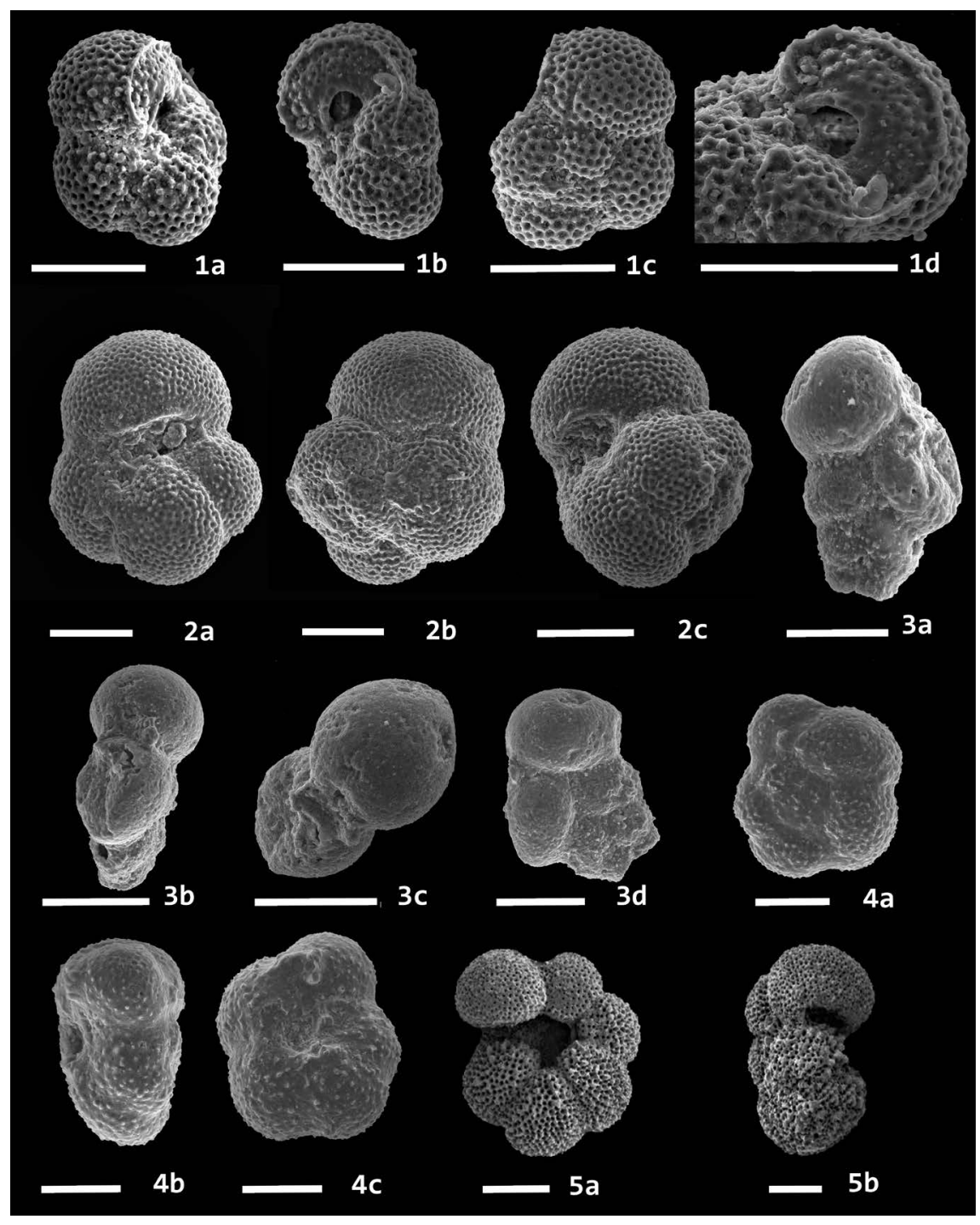

Figure 6. SEM photographs of selected planktonic foraminiferal species from the studied section in the Zgaimat Al-Hasah anticline. 1(a-d) Globorotaloides quadrocameratus (Olsson, Pearson \& Huber 2006); 2(a-c) Alicantina prolata (Bolli, 1957); 3(a-d) Chiloguembelina parallela (Beckmann, 1957); 4(a-c) Acarinina pentacamerata (Subbotina, 1947); 5(a-b) Acarinina aspensis (Colom, 1954). All scale bars $=100 \mu \mathrm{m}$.

Despite the samples that collected from the varicolored sandstones and phosphatic sandstone were barren. The Lower Eocene foraminiferal assemblages were recovered from the carbonate succession in the studied section. The Lower Eocene benthonic assemblages include, among others, Planulina dayi (White, 1928), Nonion havanense (Cushman and Bermudez, 1937), Pullenia americana (Cushman, 1936), P. jarvisi (Cushman 1936), Ammonia sp. cf. A. aomoriensis (Asano, 1951), Cribrostomoides sp. (Parr, 1950), Mississippina omuraensis (Shuto, 1953), Trochammina sp. (Cushman, 1944), Tritaxis primitiva (Brönnimann \& Whittaker, 1988), T. fusca (Williamson, 1858), Cibicides mabahethi (Said, 1949), Paratrochammina globorotaliformis (Zheng, 1988), Discorbinella bodjongensis (LeRoy, 1941). 


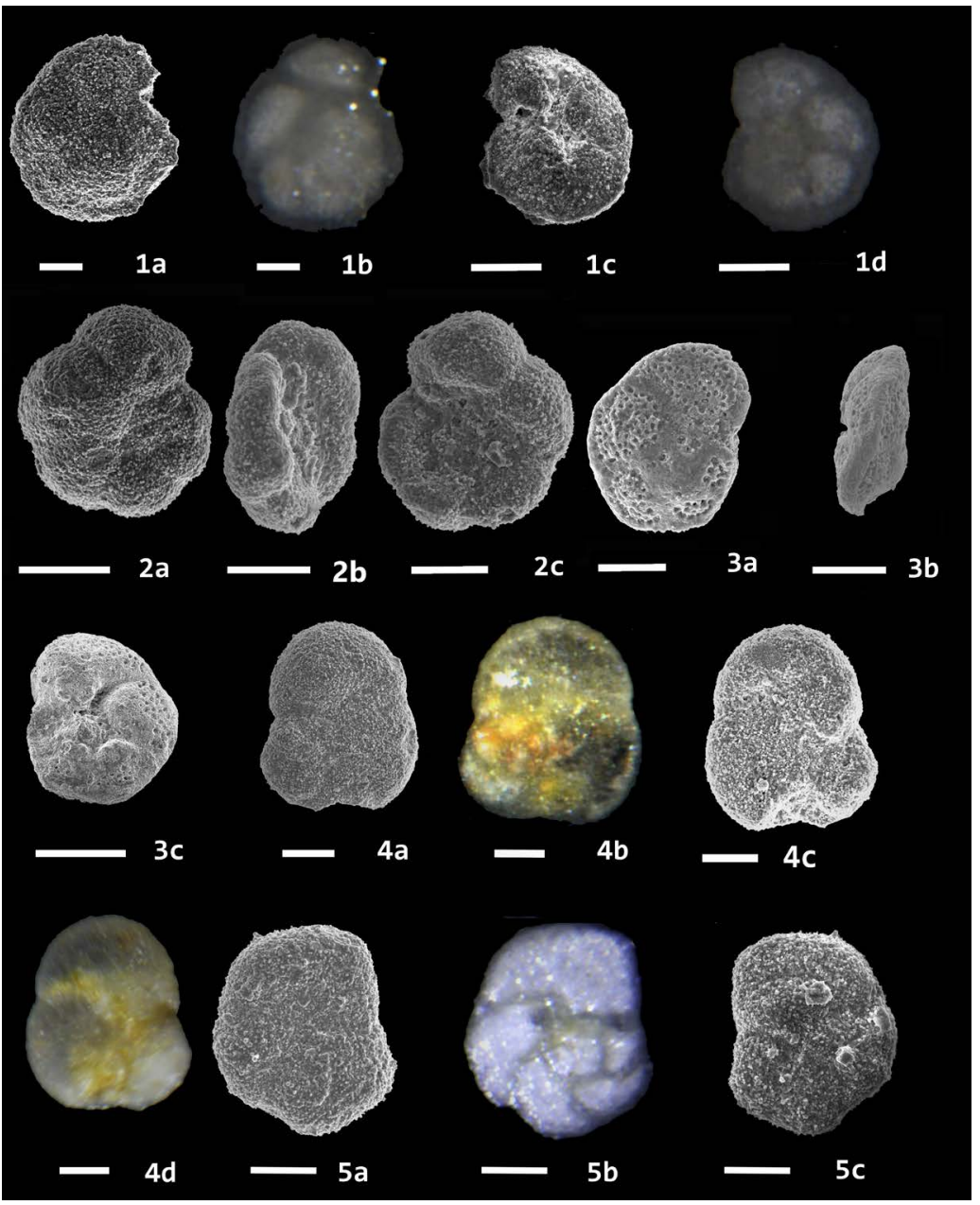

Figure 7. Selected benthic foraminiferal species from the studied section in the Zgaimat Al-Hasah anticline. 1(a-d) Ammonia cf. A. aomoriensis (Asano, 1951); 2(a-c) Cribrostomoides sp. (Parr, 1950); 3(a-c) Mississippina omuraensis (Shuto, 1953); 4(a-d) Trochammina sp. (Cushman, 1944); 5(a-c) Tritaxis primitiva (Brönnimann \& Whittaker, 1988). All scale bars $=100 \mu \mathrm{m}$.

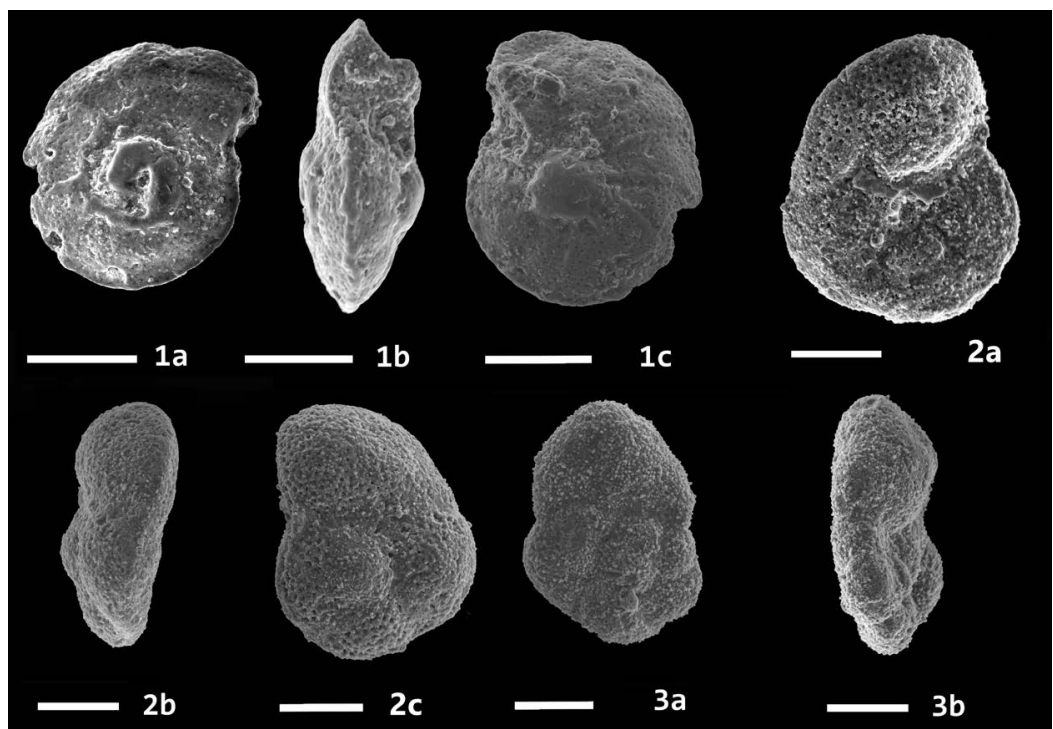




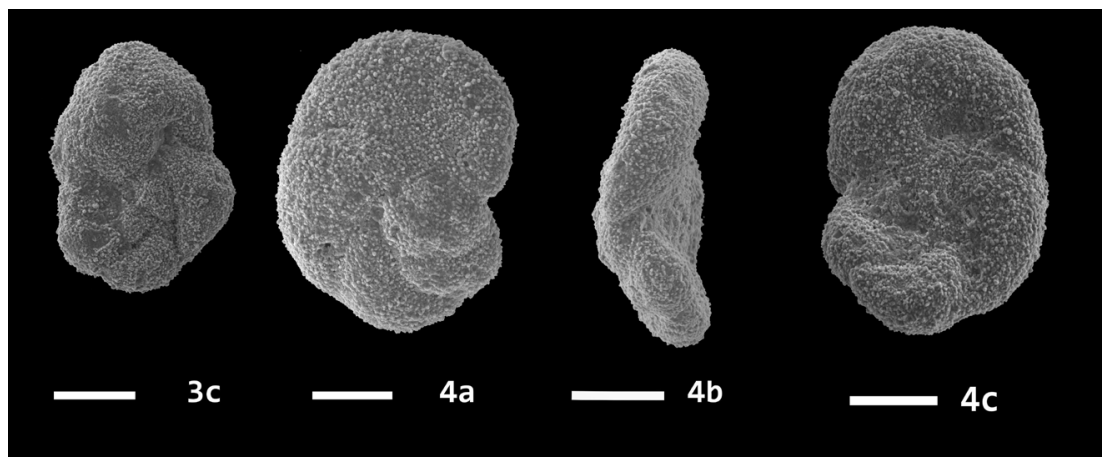

Figure 8. Selected benthic foraminiferal species from the studied section in the Zgaimat Al-Hasah anticline. 1(a-c) Cibicides mabahethi (Said, 1949); 2(a-c) Paratrochammina globorotaliformis (Zheng, 1988); 3(a-c) Discorbinella bodjongensis (LeRoy, 1941); 4(a-c) Tritaxis fusca (Williamson, 1858). All scale bars $=100 \mu \mathrm{m}$.

Based on occurrences of some age-diagnostic planktonic foraminiferal species, an Early Eocene age is given to the studied section. Whereas, the Ajlun Group at Zgaimat Al-Hasah of the Wadi Sirhan Basin probably deposited during the Cenomanian-Turonian age [4]. The Al-Hisa Phosphorite Formation (AHP) that overlies the studied section in the Zgaimat Al-Hasah anticline was deposited during the Paleocene-Early Eocene age, based on the occurrence of calcareous nannofossils [28].

\section{Conclusions}

The identification of the age-diagnostic of Planktonic Foraminiferal species is contributing to establishing the Foraminiferal biostratigraphic zones as well as the age determination of the enclosed deposits. The age-diagnostic species uses mainly to reconstruct the vertical distribution of biostratigraphic zones. In other words, to delineate the approximate positions within a standard chrono-stratigraphic scale.

The present study that is carrying out for the first time in the study area concluded the following findings;

- Five Planktonic Foraminiferal biostratigraphic zones have been detected in the studied section representing Zones E3, E4, E5, E6, and E7 or E7a.

- The occurrences of some important Planktonic Foraminiferal species indicated that the studied carbonate deposits have deposited during the Early Eocene age.

- Ten planktonic foraminiferal species belonging to seven genera have been recorded; Globorotaloides quadrocameratus (Olsson, Pearson \& Huber 2006), Alicantina prolata (Bolli 1957), Chiloguembelina parallela (Beckmann, 1957), Acarinina pentacamerata (Subbotina 1947), Acarinina aspensis (Colom 1954), Acarinina bullbrooki (Bolli 1957), Subbotina patagonica (Todd and Kniker. 1952), Subbotina eocaena (Guembel 1868), Pseudohastigerina micra (Cole, 1927), and Planorotalites pseudoscitula (Glaessner 1937)

- Thirteen benthic foraminiferal species belonging to eleven genera have 
been identified; Planulina dayi (White, 1928), Nonion havanense (Cushman and Bermudez, 1937), Pullenia americana (Cushman, 1936), P. jarvisi (Cushman 1936), Ammonia cf. A. aomoriensis (Asano, 1951), Cribrostomoides sp. (Parr, 1950), Mississippina omuraensis (Shuto, 1953), Trochammina sp. (Cushman, 1944), Tritaxis primitiva (Brönnimann \& Whittaker, 1988), T. fusca (Williamson, 1858), Cibicides mabahethi (Said, 1949), Paratrochammina globorotaliformis (Zheng, 1988), and Discorbinella bodjongensis (LeRoy, 1941).

\section{Acknowledgements}

I would like to express my special thanks and sincere gratitude to the Deanship of Scientific Research at Al al-Bayt University for funding this study. Thanks a lot to Prof. Abdalla Abu Hamad (University of Jordan) and Prof. Hani Al-Amoush (Al al-Bayt University) for their valuable comments on the first manuscript. My thanks and appreciation to Prof. Brian Huber (National Museum of Natural History, Smithsonian Institution, USA) and Prof. Bridget Wade (University College London, UK) for confirming some of the identified species in the present article. And many thanks to Prof. A. Abed, Dr. Wadah Faris, and Geo. Yousef Abu Salha for their bits of help in fieldwork. Many thanks also to Dr. Mohanad Masad, the Director of Water, Environment, and Arid Regions Research Centre at Al al-Bayt University, and the SEM's team; Eng. Aseel Al-Masry and Eng. Manal Al Essa for photographing the specimens of the present study.

\section{Conflicts of Interest}

The author declares no conflicts of interest regarding the publication of this paper.

\section{References}

[1] Quennell, A.M. (1951) The Geology and Mineral Resources of (Former) Trans-Jordan. HM Stationery Office.

[2] Bender, F. (1974) Geology of Jordan. Borntraeger, Berlin, 196.

[3] Powell, J.H. (1989) Stratigraphy and Sedimentation of the Phanerozoic Rocks in Central and South Jordan. Part B: Kurnub, Ajlun and Belqa Groups. Bulletin 11. Geological Mapping Division, Natural Resources Authority, Amman, 130 p.

[4] Khalifa, M.K. and Abed, A.M. (2010) Lithostratigraphy and Microfacies Analysis of the Ajlun Group (Cenomanian to Turonian) in Wadi Sirhan Basin, SE Jordan. Jordan Journal of Earth and Environmental Sciences, 3, 1-16.

[5] Bolli, H.M., Saunders, J.B. and Perch-Nielsen, K. (1989) Plankton Stratigraphy: Volume 1, Planktic Foraminifera, Calcareous Nannofossils and Calpionellids. CUP Archive.

[6] Berggren, W.A., Kent, D.V., Swisher, C.C. and Aubry, M.P. (1995) A Revised Cenozoic Geochronology And Chronostratigraphy. In: Berggren, W.A., Kent, D.V., Aubry, M. and Hardenbol, J., Eds., Geochronology, Time Scales and Global Strati- 
graphic Correlation, Special Publication of Society for Sedimentary Geology, Tulsa, 129-212. https://doi.org/10.2110/pec.95.04.0129

[7] Stainforth, R.M., Lamb, J.L., Luterbacher, H., Beard, J.H. and Jeffords, R.M. (1975) Cenozoic Planktonic Foraminiferal Zonation and Characteristics of Index Forms. The University of Kansas Paleontological Contributions, 62, 425 p.

[8] Boersma, A. (1988) Foraminifera. In: Haq, B.U. and Boersma, A., Eds., Introduction to Marine Micropaleontology, Elsevier Science, Singapore, 19-78. https://doi.org/10.1016/B978-044482672-5/50002-7

[9] Subbotina, N.N. (1947) Foraminifery datskikh i paleogenovykh otlozhenii severnogo Kavkaza [Foraminifera of the Danian and Paleogene Deposits of the Northern Caucasus]. Trudy Vesesoyuznogo Nauchno-Issledovatel'skogo Geologo-Razvedochnogo Neftyanogo Instituta, Novaya Seriya (VNIGNI), 39-160.

[10] Bolli, H.M. (1957) Planktonic Foraminifera from the Eocene Navet Formation and San Fernando Formations in Trinidad, B.W.I. Bulletin of the United States National Museum, 215, 155-172.

[11] Blow, W.H. (1979) The Cainozoic Globigerinida, Vol. 3, E. J. Brill, Leiden, 1452 p.

[12] Toumarkine, M. and Luterbacher, H. (1985) Paleocene and Eocene Planktic Foraminifera. In: Bolli, H.M., Saunders, J.B. and Perch-Nielsen, K., Eds., Plankton Stratigraphy, Cambridge University Press, Cambridge, 87-154.

[13] Berggren, W.A. and Miller, K.G. (1988) Paleogene Tropical Planktonic Foraminiferal Biostratigraphy and Magnetobiochronology. Micropaleontology, 34, 362-380. https://doi.org/10.2307/1485604

[14] Berggren, W.A. and Pearson, P.N. (2005) A Revised Tropical to Subtropical Paleogene Planktonic Foraminiferal Zonation. The Journal of Foraminiferal Research, 35, 279-298. https://doi.org/10.2113/35.4.279

[15] Pearson, P.N., Olsson, R.K., Huber, B.T., HemleBen, C. and Berggren, W.A. (2006) Atlas of Eocene Planktonic Foraminifera. The Cushman Foundation for Foraminiferal Research, Special Paper, 41.

[16] Qteishat, A. (1987) Wadi Sirhan Basin Evaluation. Natural Resources Authority of Jordan, Amman.

[17] Abed, A.M. and Amireh, B.S. (1999) Sedimentology, Geochemistry, Economic Potential and Palaeogeography of an Upper Cretaceous Phosphorite Belt in the Southeastern Desert of Jordan. Cretaceous Research, 20, 119-133. https://doi.org/10.1006/cres.1999.0147

[18] Holmes, M.J., Harland, W.B. and Suleiman, A.L. (1989) The Geology and Seismic Interpretation for Wadi Sirhan Area "A". Natural Resources Authority of Jordan, Amman.

[19] Bowen, R. and Jux, U. (1987) Afro-Arabian Geology: A Kinematic View. Springer Science and Business Media, Berlin.

[20] Powell, J.H. and Moh'd, B.K. (2011) Evolution of Cretaceous to Eocene Alluvial and Carbonate Platform Sequences in Central and South Jordan. GeoArabia, 16, 29-82.

[21] Haq, B.U., Hardenbol, J. and Vail, P.R. (1988) Mesozoic and Cenozoic Chronostratigraphy and Eustatic Cycles. In: Wilgus, C.K., Hastings, B.S., Kendall, G.St.C., Possamentier, H.W., Ross, C.A. and Van Wagoner, J.C., Eds., Sealevel Changes: An Integrated Approach, Society of Economic Palaeontologists and Mineralogists, Special Publication No. 42, 71-108. https://doi.org/10.2110/pec.88.01.0071

[22] Sharland, P.R., Archer, R., Casey, D.M., Davies, R.B., Hall, S.H., Heward, A.P., Horbury, A.D. and Simmons, M.D. (2001) Arabian Plate Sequence Stratigraphy. 
GeoArabia Special Publication 2. Gulf Petrolink Bahrain. 371 p.

[23] Burdon, D.J. (1959) Handbook of the Geology of Jordan. Government of Jordan, Amman, 82.

[24] Read, J.F. (1985) Carbonate Platform Facies Models. American Association of Petroleum Geologists Bulletin, 69, 1-21. https://doi.org/10.1306/AD461B79-16F7-11D7-8645000102C1865D

[25] Flexer, A., Rosenfeld, A., Lipson-Benitah, S. and Honigstein, A. (1986) Relative Sea-Level Changes during the Cretaceous in Israel. American Association of Petroleum Geologists Bulletin, 70, 1685-1699. https://doi.org/10.1306/94886C9A-1704-11D7-8645000102C1865D

[26] Urchette, T.P. and Wright, V.P. (1992) Carbonate Ramp Depositional Systems. Sedimentary Geology, 79, 3-57. https://doi.org/10.1016/0037-0738(92)90003-A

[27] Parker, D.H. (1970) The Hydrogeology of the Mesozoic-Cainozoic Aquifers of the Western Highlands and Plateau of East Jordan. Investigation of the Sandstone Aquifers of East Jordan. Technical Report No. 2, 212, 424.

[28] Amireh, B.S., Mutterlose, J., Amaireh, M.N., Puettmann, T. and Abed, A.M. (2018) Biostratigraphy and Paleogeography of the Southeast Desert Phosphorites of Jordan. Arabian Journal of Geosciences, 11, 425.

https://doi.org/10.1007/s12517-018-3768-Z

[29] Wade, B.S., Pearson, P.N., Berggren, W.A. and Pälike, H. (2011) Review and Revision of Cenozoic Tropical Planktonic Foraminiferal Biostratigraphy and Calibration to the Geomagnetic Polarity and Astronomical Time Scale. Earth-Science Reviews, 104, 111-142. https://doi.org/10.1016/j.earscirev.2010.09.003

[30] Premoli Silva, I. and Petrizzo, M.R. (2006) Practical Manual of Eocene Planktonic Foraminifera. International School on Planktonic Foraminifera, Universita degli Studi di Perugia, Universita degli Studi di Milano, Perugia, $248 \mathrm{p}$.

[31] Huber, B.T., Petrizzo, M.R., Young, J.R., Falzoni, F., Gilardoni, S.E., Bown, P.R. and Wade, B.S. (2016) Pforams@ Microtax. Micropaleontology, 62, 429-438.

[32] Boltovskoy, E., Giussani, G., Watanabe, S. and Wright, R.C. (2012) Atlas of Benthic Shelf Foraminifera of the Southwest Atlantic. Springer Science and Business Media, Berlin.

[33] Debenay, J.P. (2012) A Guide to 1,000 Foraminifera from Southwestern Pacific: New Caledonia. IRD Editions.

[34] Hulsbos, R.E., Kroon, D., Jansen, H.S.M. and Van Hinte, J.E. (1989) Lower Eocene Benthic Foraminifera and Paleoenvironment of the Outer Voring Plateau, Norwegian Sea (DSDP Site 338). Micropaleontology, 35, 256-273. https://doi.org/10.2307/1485683

[35] Leoblich, A.R. and Tappan, H. (1988) Foraminiferal Genera and Their Classification. Vand Nostrand Reinhold Company, New York, 970 p. https://doi.org/10.1007/978-1-4899-5760-3

[36] Loeblich, J. and Tappan, H. (1994) Foraminifera of the Sahul Shelf and Timor Sea. Cushman Foundation for Foraminiferal Research, Special Publication No. 31, 663.

[37] Wetzel, R. and Morton, D.M. (1959) Contribution a la geologie de la Transjordanie. Notes et Memoirs sur le Moyen Orient, 7, 95-191.

[38] Basha, S.H. (1978) Foraminifera from the Ajlun Group of East Jordan. Journal of the Geological Society of Iraq, 11, 67-91.

[39] Dilley, F.C. (1985) Cretaceous Correlations in the Hamza Wells 1-5. Natural Resources Authority, Palaeontological Report, 6. 
[40] Masri, M. (1963) Report on the Geology of the Amman-Zerqa Area. Central Water Authority, Amman, 1-74.

[41] Cande, S.C. and Kent, D.V. (1995) Revised Calibration of the Geomagnetic Polarity Timescale for the Late Cretaceous and Cenozoic. Journal of Geophysical Research: Solid Earth, 100, 6093-6095. https://doi.org/10.1029/94JB03098

[42] Luterbacher, H.P., Ali, J.R., Brinkhuis, H., Gradstein, F.M., Hooker, J., Monechi, S., Ogg, J.G., Powell, J., Röhl, U., Sanfilippo, A. and Schmitz, B. (2004) The Paleogene Period. In: Gradstein, F., Ogg, J. and Smith, A., Eds., A Geologic Time Scale 2004, Cambridge University Press, Cambridge, 384-408. https://doi.org/10.1017/CBO9780511536045.021

[43] Olsson, R.K. and Hemleben, C. (2006) Taxonomy, Biostratigraphy, and Phylogeny of Eocene Globanomalina, Planoglobanomalina n. gen and Pseudohastigerina. In: Pearson, P.N., Olsson, R.K., Hemleben, C., Huber, B.T. and Berggren, W.A., Eds., Atlas of Eocene Planktonic Foraminifera, Cushman Foundation for Foraminiferal Research, Special Publication 41, Chap. 14, 413-432.

[44] Berggren, W.A., Pearson, P.N., Huber, B.T. and Wade, B.S. (2006) Taxonomy, Biostratigraphy and Phylogeny of Eocene Acarinina. Atlas of Eocene Planktonic Foraminifera. Cushman Foundation Special Publication 41, 257-326.

[45] Olsson, R.K., Hemleben, C., Huber, B.T. and Berggren, W.A. (2006) Taxonomy, Biostratigraphy, and Phylogeny of Eocene Globigerina, Globoturborotalita, Subbotina, and Turborotalita. In: Pearson, P.N., Olsson, R.K., Hemleben, C., Huber, B.T. and Berggren, W.A., Eds., Atlas of Eocene Planktonic Foraminifera, Cushman Foundation for Foraminiferal Research, Special Publication 41, Chap. 6, 111-168.

[46] Wade, B.S., Olsson, R.K., Pearson, P.N., Edgar, K.M. and Premoli Silva, I. (2018) Taxonomy, Biostratigraphy, and Phylogeny of Oligocene Subbotina. In: Wade, B.S., Olsson, R.K., Pearson, P.N., Huber, B.T. and Berggren, W.A., Eds., Atlas of Oligocene Planktonic Foraminifera, Cushman Foundation for Foraminiferal Research, Special Publication 46, Chap 10, 307-330.

[47] Soldan, D.M., Petrizzo, M.R. and Silva, I.P. (2018) Alicantina, a New Eocene Planktonic Foraminiferal Genus for the Lozanoi Group. Journal of Foraminiferal Research, 48, 41-52. https://doi.org/10.2113/gsjfr.48.1.41

[48] Olsson, R.K., Pearson, P.N. and Huber, B.T. (2006) Taxonomy, Biostratigraphy, and Phylogeny of Eocene Catapsydrax, Globorotaloides, Guembelitrioides, Paragloborotalia, Parasubbotina, and Pseudoglobigerinella n. gen. In: Pearson, P.N., Olsson, R.K., Hemleben, C., Huber, B.T. and Berggren, W.A., Eds., Atlas of Eocene Planktonic Foraminifera, Cushman Foundation for Foraminiferal Research, Special Publication 41, Chap 5, 67-110.

[49] Coxall, H.K. and Spezzaferri, S. (2018) Taxonomy, Biostratigraphy, and Phylogeny of Oligocene Catapsydrax, Globorotaloides, and Protentelloides. Cushman Foundation for Foraminiferal Research, Special Publication 46, 79-124. 